\title{
Architecture and development of the alluvial sediments of the Upper Jurassic Tordillo Formation in the Cañada Ancha Valley, northern Neuquén Basin, Argentina
}

\author{
José López-Gómez ${ }^{\mathrm{a}, *}$, Javier Martín-Chivelet ${ }^{\mathrm{a}}$, Ricardo M. Palma ${ }^{\mathrm{b}}$ \\ anstituto de Geologí Económica, Departamento de Estratigrafia (CSIC-UCM), Facultad de Geologí, Universidad Complutense de Madrid C/Antonio Nováis 2, 28040 Madrid, Spain \\ ${ }^{b}$ Departamento de Ciencias Exactas y Naturales, Universidad de Buenos Aires-CoNICET, Pabellón II, 1428 Buenos Aires, Argentina
}

Keywords:

Tordillo Formation

Neuquén Basin

Back-arc basin

Kimmeridgian

Alluvial architecture

Argentina

\begin{abstract}
A B S T R A C T
The Upper Jurassic Tordillo Formation at Cañada Ancha area, northern Neuquén Basin, Argentina, comprises a multi-stage suit of predominantly alluvial sediments that is heterolithic in nature. In that suit, several lithofacies, architectural elements, and bounding surfaces of different order have been identified and their lateral and vertical distribution characterized. This analysis allowed the differentiation of 3 main units (lower, middle and upper), 20 subunits ( $C-1$ to $C-20$ ), and the characterization of their alluvial styles.

The lower unit (which comprises subunits $C-1$ to $C-4$ ) is mainly formed by fine- to medium-grained sandstones, which become medium- to coarse-grained towards the top. These sandstones characterize settings ranging from floodplains with isolated, unconfined flows, to more complex, vertically stacked, multistorey sheet sandstones of braided fluvial systems. The middle unit ( $C-5$ to $C-10$ ) is dominated by pale browngrey fine-to coarse-grained sands and medium size subangular to angular conglomerates, which reflect amalgamated complexes of sandstone sheets and downstream accretion macroforms. Remarkably, this alluvial sedimentation was episodically punctuated by volcaniclastic flows. The upper unit (C-11 to C-20) consists of finer sediments, mainly pink to white fine-to medium grained sandstones and red to green siltstones. Towards the top, bioturbation becomes important, and also the presence of volcanosedimentary flows is noticeable. Fluvial settings include braided sheet sandstones with waning flood deposits evolving to isolated high-sinuosity fluvial systems, with flash flood deposits. At the top of this unit, facies may suggest marine influence.

Vertical changes in the fluvial style result from both climatic and tectonic controls. A semiarid to arid climate and the active tectonism linked to the eastward migration of the Andean volcanic arc determined major bounding surfaces, fluvial style evolution and the presence of the volcano-sedimentary deposits. Different stages of high and low subsidence rates has been deduced from the vertical stacking of sediments.
\end{abstract}

\section{Introduction}

The application of concepts on fluvial architecture and sandstonebody-form (Allen, 1983; Friend, 1983; Miall, 1985; Hirst, 1991; Miall, 1994, 1996; Jones et al., 2001) has clearly improved the knowledge of fluvial sequences, and a vast number of fluvial depositional systems developed under different tectonic and climatic conditions have been characterized under such a philosophy in the last decades. Despite that proliferation of works, still few case-studies document the fluvial sedimentology and architecture of back-arc basins, or include detailed geometric descriptions of an entire complex of a vertical stacking of different fluvial systems in that tectonic setting.

Fielding et al. (1993) provided a detailed description and interpretation of an alluvial succession of latest Permian age during

\footnotetext{
* Corresponding author. Tel.: +34913944808.

E-mail addresses: jlopez@geo.ucm.es (J. l.ópez-Gómez),j.m.chivelet@geo.ucm.es (J. Martín-Chivelet),palma@gl.feen.uba.ar (R.M. Palma).
}

a period of arc volcanism and thrust loading in the Bowen Basin, Australia. Depositional processes of primary to reworked volcaniclastics on an alluvial plain were described by Nakayama and Yoshikawa (1997) in the Lower Pliocene Ohta tephra bed of the Tokai Group in the Japan arc-trench system. This paper provides a very good example relating changes of fluvial systems promoted by volcanic eruptions. Recently, Paredes et al. (2007a,b) described a case of climatic and volcanic controls on the fluvial style in the Lower Cretaceous Matasiete Formation, Golfo de San Jorge intracratonic basin, Argentina. This work provides an interesting description of the impact of pyroclastic input into the drainage system and the floodplain. Similar examples of pyroclastic input controlling the drainage system in basins located near areas of volcanic activity are described by Cas and Wright (1987) and Fisher and Smith (1991).

Under that perspective, we present an example of the Tordillo Formation. The formation was deposited in a broad extension of the Neuquén Basin (Argentina) in continental sedimentary conditions, mainly alluvial but also of eolian origin, and under volcanic, tectonic and climatic controls (e.g., Legarreta and Uliana, 1996, 1999; Spalletti 
and Colombo, 2003; Zavala et al., 2005). This work try to contribute to previous studies by describing the controls on sedimentology, stratigraphy and depositional architecture of the Tordillo Formation.

The unit is classically referred, on the basis of its stratigraphical position, to Kimmeridgian and lower Tithonian, a time which the basin evolved as a postrift/ back-arc basin (Legarreta and Uliana, 1996; Ramos, 1999; Schwartz et al., 2006). The deposits of the Tordillo Formation correspond to the onset of a major genetic unit, and record a drastic change in subsidence and paleogeography in the basin (Mitchum and Uliana, 1985; Legarreta and Uliana, 1991; Gulisano and Gutierrez-Pleimling, 1994). The study of this unit has been of great interest during the last three decades as it represents a classical well known hydrocarbon reservoir in the Neuquén basin.

Our study is centred in the excellent outcrops of the Tordillo Formation in the Cañada Ancha, Salado River Valley (Mendoza Province) (Fig. 1). These outcrops are very well exposed and represent the whole Tordillo Formation, which show ideal conditions for a detailed analysis of the fluvial architecture in relation with structural and climate controls.

\section{Geological setting}

The Neuquén Basin is a Mesozoic back-arc basin that today is located in central-western Argentina and eastem Chile, between latitudes $32^{\circ}$ and $40^{\circ} \mathrm{S}$. In Argentina, the basin occupies part of the Mendoza, Neuquén, Río Negro and La Pampa Provinces, reaching a lateral extension of more than $120,000 \mathrm{~km}^{2}$. The Neuquén Basin is now incorporated into the Andean retro-arc foreland basin.

Various papers have described the main phases of evolution and relationships between sedimentation and tectonics of this basin, including Groeber (1946), Digregorio and Uliana (1980), Gulisano et al. (1984), Mitchum and Uliana (1985), Legarreta and Gulisano (1989), Vergani et al. (1995), Legarreta and Uliana $(1991,1996)$ among others. Legarreta and Gulisano (1989) described four successive tectonic episodes of basin development: (a) rifting (Iate TriassicEarly Jurassic), (b) thermal subsidence (Early Jurassic-Late Cretaceous), (c) subsidence due to loading (Late Cretaceous-Early Cenozoic), and (d) Andean tectonism (Early Cenozoic-Quaternary). For the Early Jurassic-Early Cretaceous interval of time, Schwartz et al. (2006) also proposed a postrift/back-arc phase. Vergani et al. (1995), however, consider that the thermal subsidence that characterized the Jurassic-Cretaceous interval was not uniform, but punctuated by several episodes of structural inversion. Ploszkiewicz et al. (1984) explained that these changes from compression to extension in some areas of the Neuquén Basin as a result of alternating transpression and transtension within a wrench fault system. This latter interpretation could explain the important regional thickness variations shown by the Tordillo Formation in the Neuquén basin.

In the Late Jurassic, after one of these phases of tectonic inversion (Araucarian inversion), a new phase of basin subsidence took place (Vergani et al., 1995), allowing and controlling deposition of the Tordillo Formation (Fig. 2) by normal faults (Cegarra and Ramos (1996). Sedimentation of this unit was thus related to a general new reorganization of the basin, with growth and eastward migration of the volcanic arc (Gulisano and Gutierrez-Pleimling, 1995).

The Neuquén Basin was one of the largest continental basins developed during the Mesozoic in the South America plate, when the western margin of this plate was the site of an active trench and a relatively narrow magmatic arc (Giambiagi et al., 2008). A series of NNW trending depocentres were developed under these conditions into the basin. The tectonic differences between the western and eastern margins and the possible network of previously developed transfer faults in some areas of the Neuquén Basin probably conditioned the development of different styles of sedimentation of the Tordillo Formation and also the drastic changes in thickness shown by this unit. Paleoflow trends of this unit were to the N-NW, broadly parallel to the volcanic arc axis (Schwartz et al., 2006).

\section{Methodology}

In the Cañada Ancha area, incision produced by the Salado River and its tributaries has developed cliff sections allowing close threedimensional inspection of the sedimentary structures, bounding surfaces, and facies of the Kimmeridgian-Tithonian siliciclastic sediments. For the architectural element analysis, a total of five partial detailed sections were measured, recording a general composite stratigraphic section for the study area. These sections are separated less than $4 \mathrm{~km}$ between them and are included into two outcrops located in the Cañada Ancha valley (Fig. 1, down, to the right, $\mathrm{A}$ and $\mathrm{B}$ ).

The study was combined with the construction of photomosaics and lithofacies differentiation in order to recognize the overall lateral variability and sandbody geometry following detailed mapping of bedding contacts. As a result, several architectural elements based on Miall's $(1985,1992)$ classification were defined. The vertical sections allowed the recognition of different order bounding surfaces. Some of these surfaces separate units and subunits within the Tordillo Formation.

The sedimentological work was completed with the characterization of width-depth relationships in the channelized bodies, the collection of paleocurrent data, the analysis of vertical variability of grain-clast sizes and the identification of different types of sequences. The type of interconnections among body forms and the vertical stacking pattern of the recognized architectural elements allowed for the recognition of the alluvial style for the individual subunits and for the Tordillo Formation as a whole.

\section{Stratigraphy}

In the study area, the sediments of the Tordillo Formation are dominated by mixed coarse-grained sandstones, medium- to coarsegrained sandstones, fine-grained sandstones and reddish and greenish siltstones. Petrographically, sandstones range from litharenites to arkoses and greywackes. Grain roundness mostly varies from subrounded to subangular and normally size does not exceed $3.5 \mathrm{~mm}$ for the entire formation. Although they are generally pale pink, colours vary and may show red, grey, brown and ochre hues. Very few and isolated levels of breccia and white to grey subrounded conglomerates also occur.

Five vertically continuous outcrops (Fig. 3) located in both sides of the Salado River and the road that links Malargüe and Las Leñas represent a complete field section of the Tordillo Formation from base to top (Fig. 4). The lower contact of the section represents an unconformity on the evaporates of the Auquilco Formation (Oxfordian) which show paleokarst features as a result of gypsum dissolution prior to the deposition of the Tordillo Formation, while the upper contact represents a sharp and abrupt change to the open marine black shales of the Vaca Muerta Formation. The dip of the unit is variable but never exceeds $27^{\circ}$. The total thickness reaches $425 \mathrm{~m}$.

Rank of bounding surfaces has been differentiated in the studied section following Miall's $(1992,1996)$ criteria. Based on a detailed study of the lithologies and the sedimentary structures of the rocks, a total of 20 subunits ( $\mathrm{C}-1$ to $\mathrm{C}-20$ ) have been differentiated, separated by major boundary surfaces. These probably represent extensive, regional surfaces separating channel belt complexes and entire fluvial systems (Figs. 3, 4). Depending on their lateral extent and regional significance, they could be considered as 6 th, 7 th or 8 th order boundary surfaces in the hierarchical classification of Miall (1992, 1996). Further work in wider areas will help to precise the hierarchy of these higher-rank surfaces. 

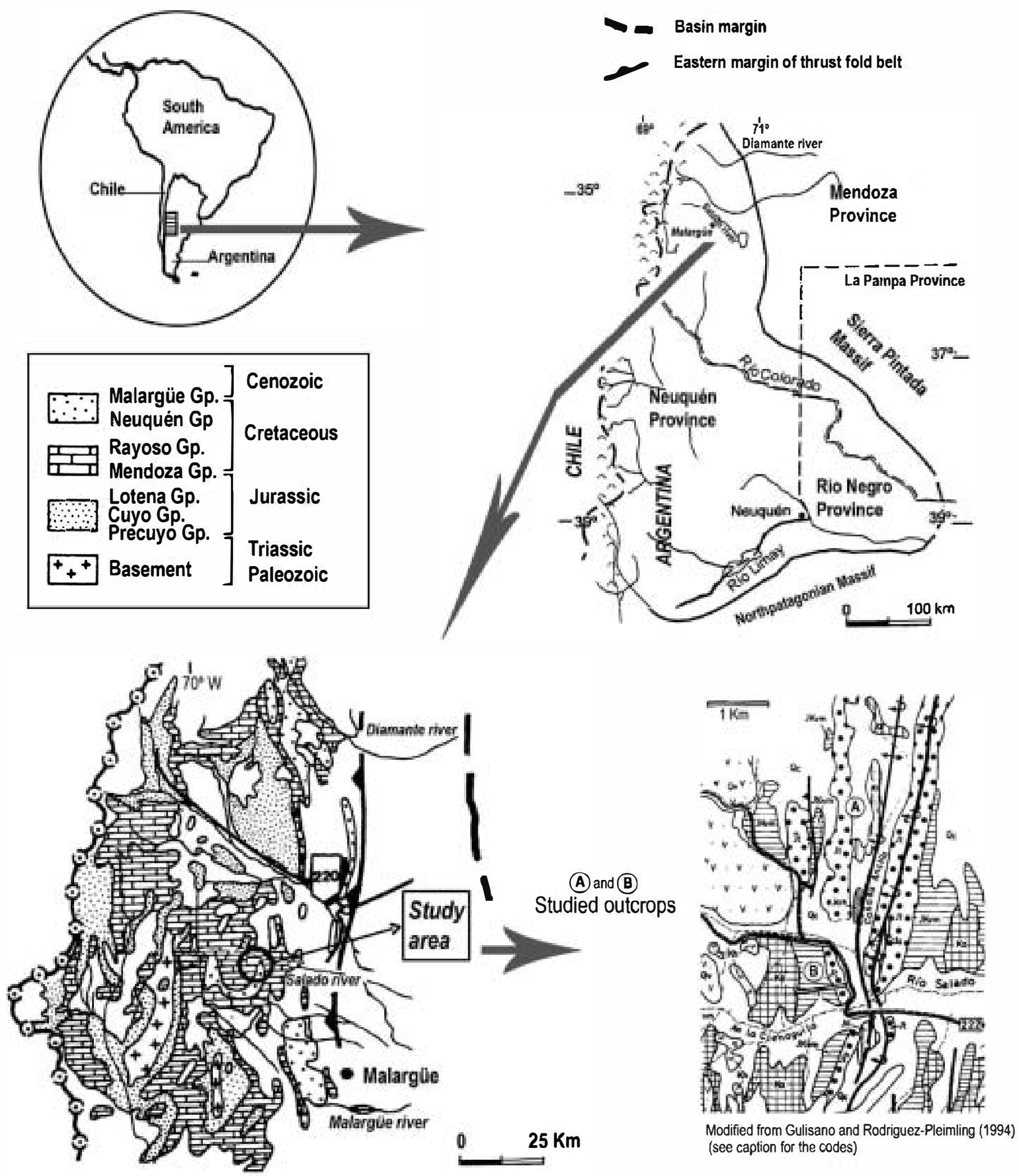

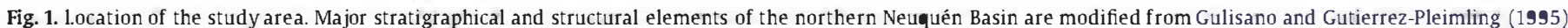
Codes: Qc - Clastics, Qv - Volcanics, JKvm - Vaca Muerta Fm. - Chachao, Jt - Tordillo Fm., Ja Auquilco Fm., Kh - Huitrín Fm., Ka - Agrio Fm.

Some of the subunits are separated by an erosive unconformity that represents a sudden vertical change in the sedimentary characteristics of the rocks. Often, this surface is flat, but with clear regional significance. Fining and coarsening-upwards sequences can also be differentiated. They are named simple when isolated and composed when formed by the vertical stacking of different bodies of the same tendency. Siltstones dominate both at the lower and upper unit of the section while the middle unit is mainly dominated by 


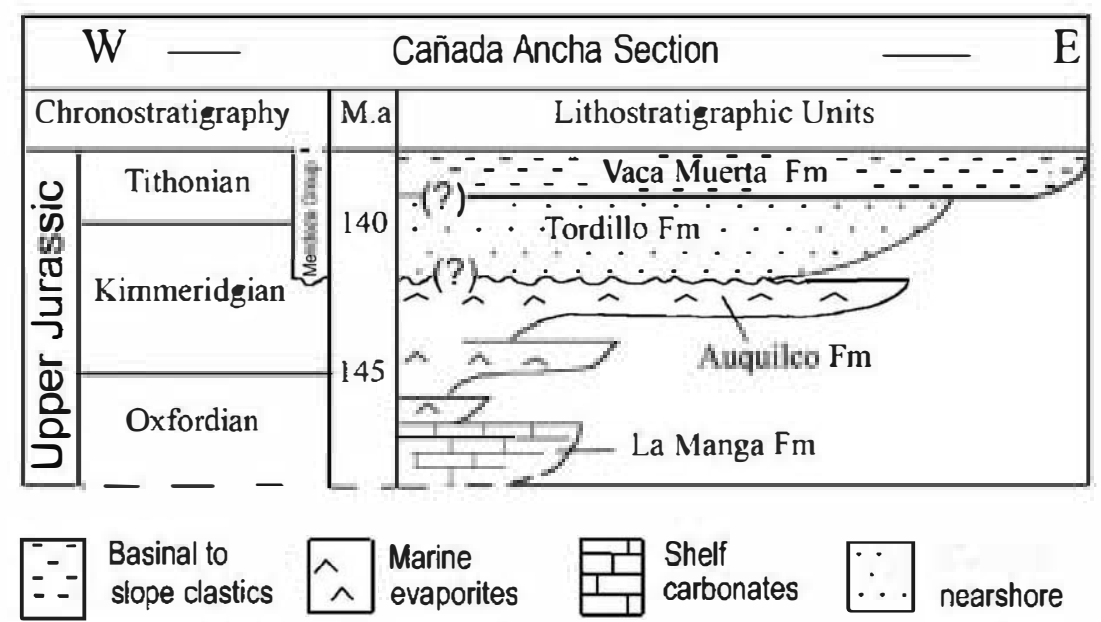

Fig. 2. Chronostratigraphic chart for the Oxfordian-Tithonian of the study area.

sandstones. Isolated levels of matrix-supported conglomerates appear mainly in subunit C-5. Measured paleocurrents were mainly obtained from planar and trough cross-bedding, flute cast and parting lineation structures. They grade vertically in the section from a $\mathrm{N}$ to NW trend in the lower half to a $W$ trend in the upper third of the section.
In general, very few organic remains are found in the whole Tordillo Formation in the study area. Isolated, unidentified plant remains, incipient and poorly preserved paleosols $(2-3 \mathrm{~cm}$ of vertical development) and roots, and punctual bioturbation structures are the only indicators of biological activity.
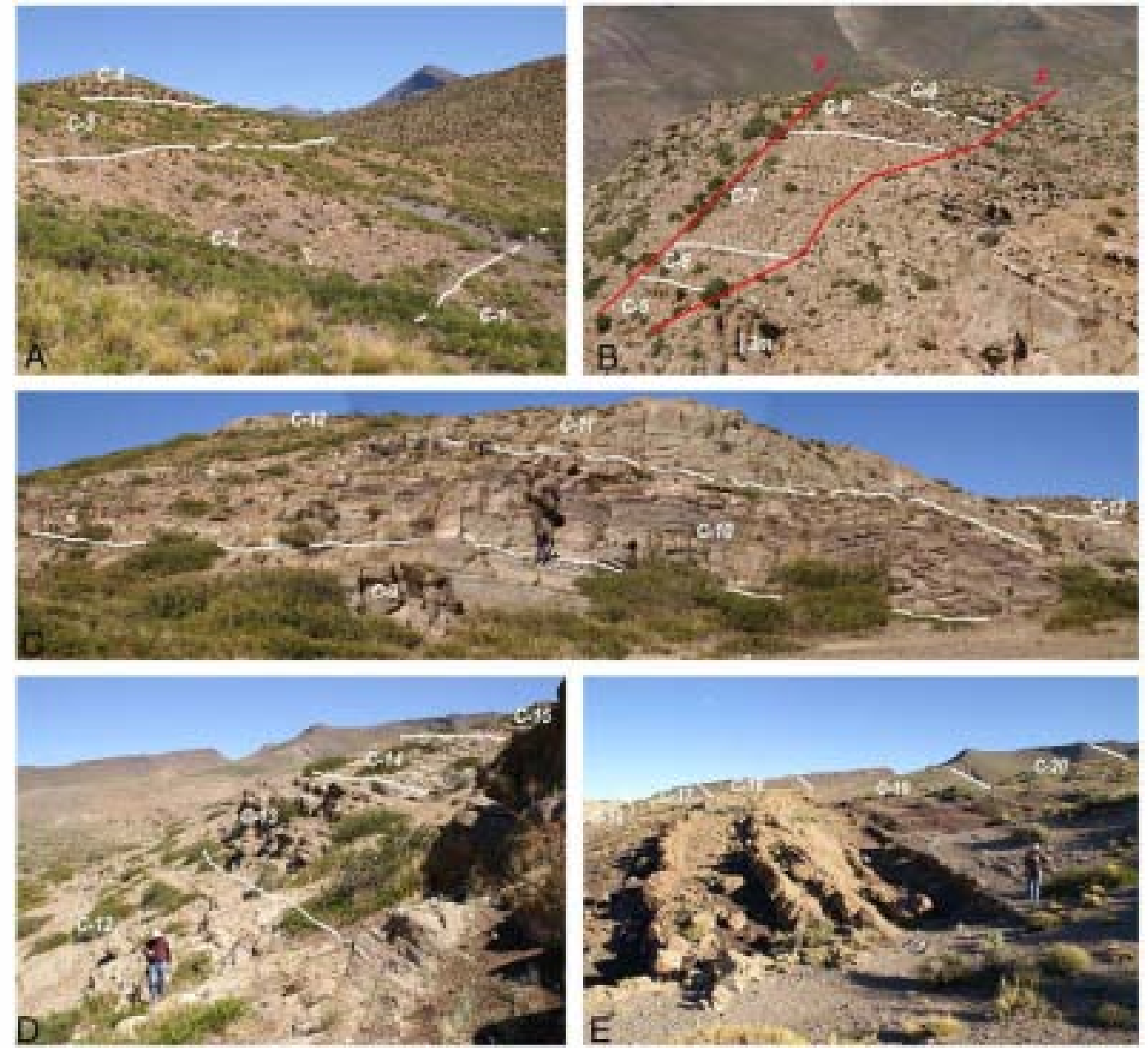

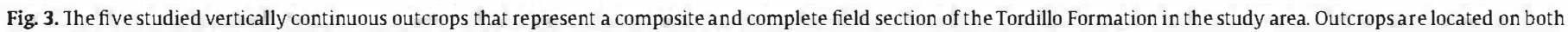
sides of the Salado River. Codes (C-1 to C-20) indicate the differentiated subunits and lines represent major boundaries surfaces. 
Legend

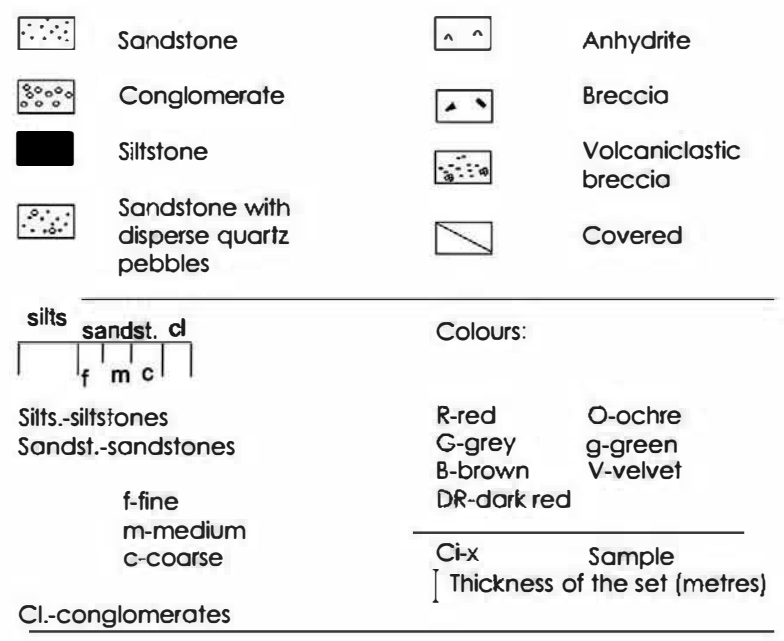

Sequences:

finning-upwords:

Coarsening-upwards:

$\begin{array}{lll}\Delta \text { Simple } & \text { Composed } & \text { Composed } \\ & & \\ \text { Clasts: } & & \\ \text { So-Subangular. a-angular. } & \text { Sr-Subrounded } \\ \text { O-main size clast (centimetres) } & \end{array}$

Sedimentary and organic structures:

\section{‥ Planar Cross-bedding \\ $\sim$ Irough Cross-bedding \\ $\triangle$ Lateral accretion \\ $=$ Parallel lamination \\ Large-scale Planar beds \\ $\approx$ Hummocky cross-stratification \\ rr Dissolution-karst \\ - Centimetre-scale \\ Angle of the planar cross-bedding \\ Halite crystal pseudomorph \\ teasal log \\ Al Plant remains \\ तT "Washed level" \\ High iron content}

Biofurbation:

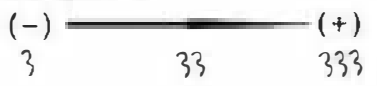

Climbing ripples

Wove ripples

Current ripples

Desiccation cracks

Lenticular bedding

Parting lineation

"Shale chips"

000 Clast-supported gravel

(2) Volcanic bomb

2 Small-scope Slide-slump

\section{- - Water-scape} structure (loads
and pseudonodules)

Flame structure

Load cost

Roots

Levels with high organic content

other structures:

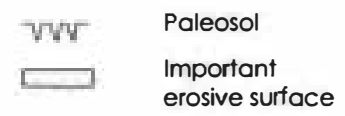

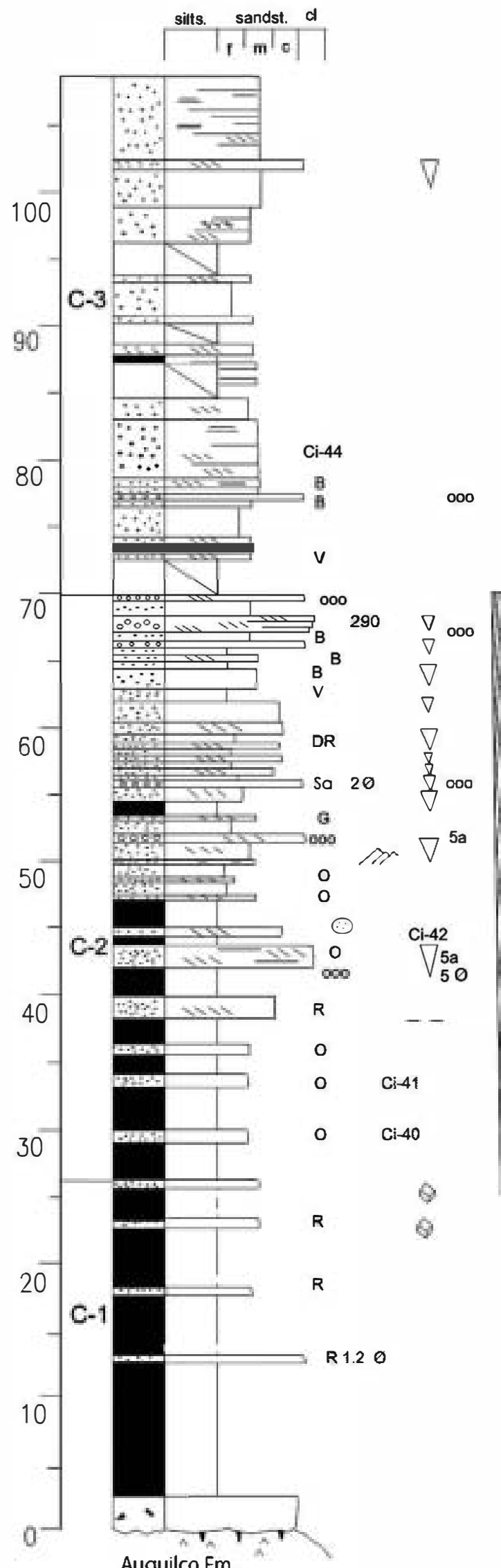

Auquilco Fm.

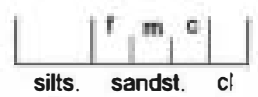

Fig. 4. Composite log of the Tordillo Formation in the Cañada Ancha area showing the main stratigraphycal and sedimentary characteristics. 


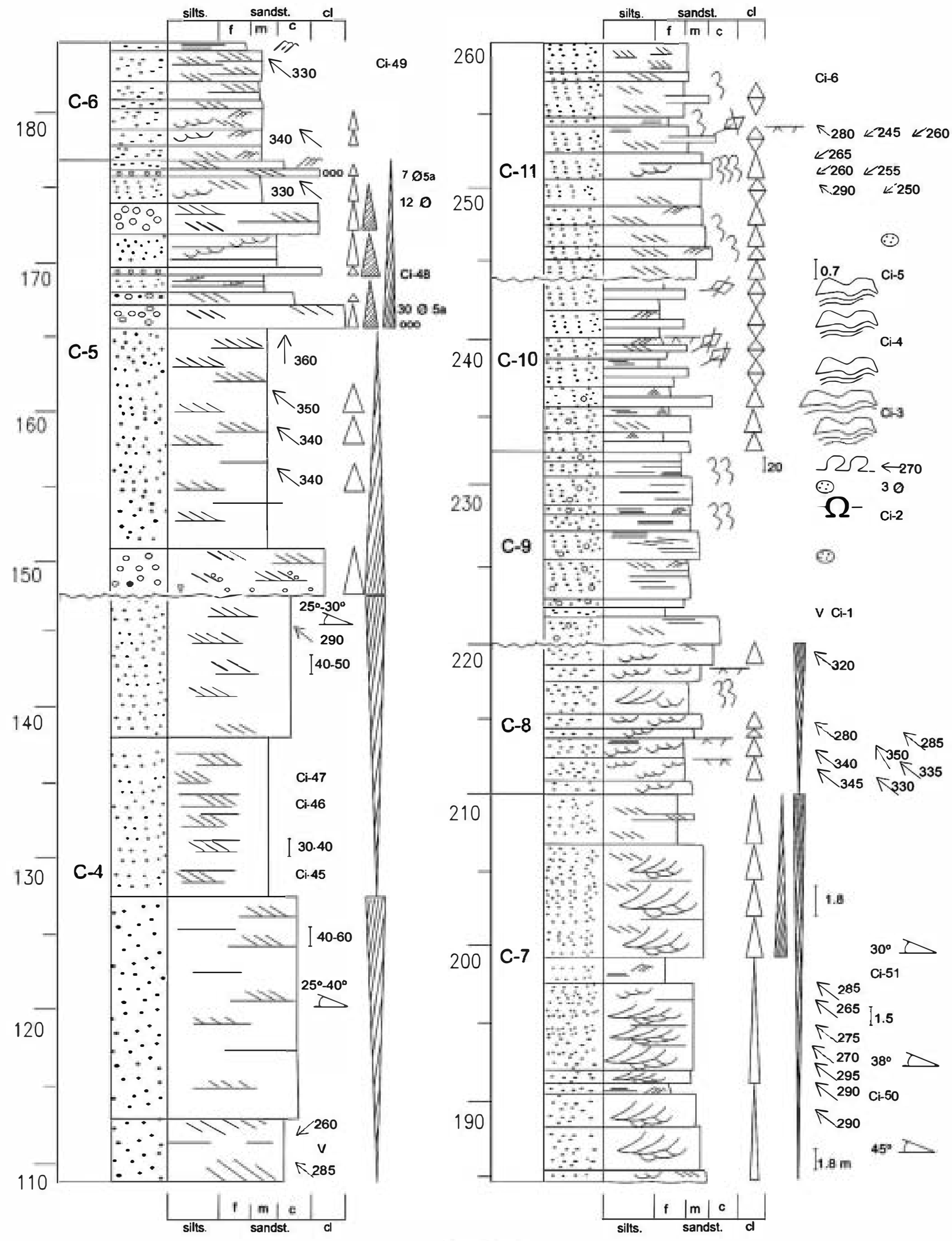

Fig. 4 (continued). 


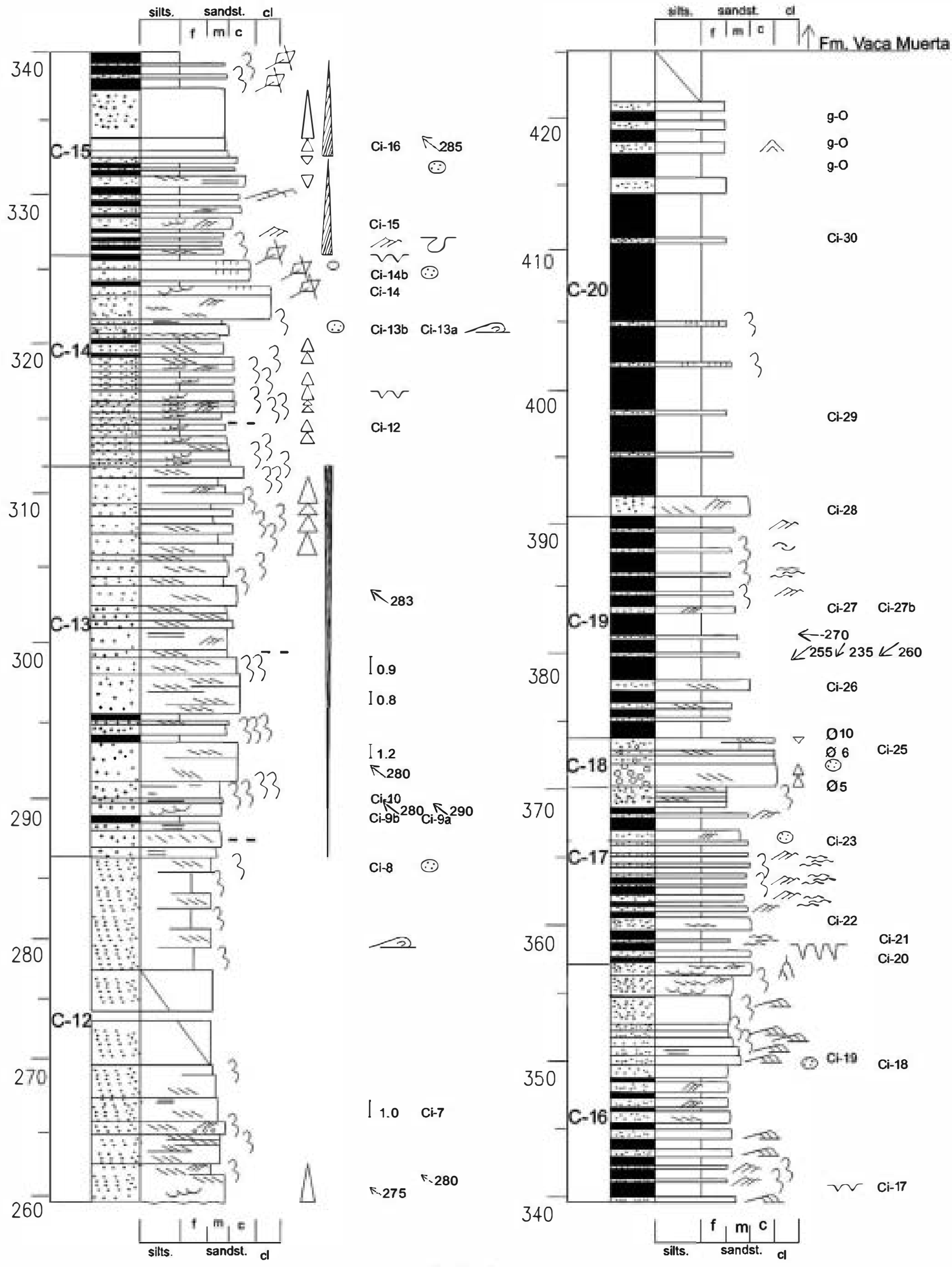

Fig. 4 (continued). 
Summarized information of the stratigraphy and sedimentary characteristics of the studied section is shown in Fig. 4.

\section{Lithofacies and architectural elements}

Bounding surfaces have typical geometrical shapes, geographical extent and enclosed lithofacies associations (Allen, 1983; Ramos and Sopeña, 1983; Miall, 1991). Channels and bars are the main depositional elements of river deposits, while the architectural elements are the sediments which are associated in those components. All of these elements are composed by facies and facies associations that characterize an individual body unit where internal geometry and external form can be differentiated (Soegaard, 1992; Bridge, 1993).

The subdivision of the Tordillo Formation into twenty subunits, based on major and minor order bounding surfaces and facies differentiation, does not have any formal stratigraphic significance. Each of these subunits displays clear lateral continuity in the study area and is characterized by a series of facies that constitute architectural elements that are externally and internally limited by bounding surfaces. A detailed scheme of these sedimentological characteristics for each subunit is shown in Figs. 5 and 6 and will therefore, not described in detail here. These figures also describe the vertical stacking pattern of the architectural elements allowing a complete sedimentological and depositional interpretation of each subunit and comparison with other similar previously described examples in the literature.

The facies code and architectural elements of this work (Table 1) are based on Miall's $(1992,1996)$ classification, including some new codes that have been added by the authors. These elements are related here to channels and floodplains. The new added codes try to describe some particular cases of our study, as those referring to vulcanosedimentary deposits, where letter $v$ is added to some Miall's codes, as shown in Table 1.

\section{Alluvial style evolution}

Based on the vertical stacking patterns of the architectural elements and major bounding surfaces of the Tordillo Formation (Figs. 3, 4) it is possible to differentiate three main units: lower, middle and upper. The lower unit shows isolated or amalgamated bodies intercalated in fine sediments and is composed of subunits $\mathrm{C}-1$

\begin{tabular}{|c|c|c|c|c|c|c|}
\hline Subunit & Facies & & $\begin{array}{l}\text { Architectural elements } \\
\text { Channel B- Floodplain } \\
\text { C- Volcaniclastics }\end{array}$ & \begin{tabular}{|l|} 
Bounding \\
surfaces \\
order
\end{tabular} & $\begin{array}{l}\text { Vertical stacking pattern } \\
\text { of architectural elements }\end{array}$ & Interpretation \\
\hline$C-1$ & $\begin{array}{l}\text { Fl(hc), } \\
\text { Ss }\end{array}$ & B & $\left.\stackrel{\mathrm{FF}}{=}{ }^{3}\right|_{\mathrm{m}} ^{0.5}$ & 3th & $\left.\frac{--}{-\underline{-}}\right|^{5 \mathrm{~m}}$ & $\begin{array}{l}\text { Floodolain fines including overbank } \\
\text { (levee and crevasse splay) deposits } \\
\text { and isolated ribbon sandstones } \\
\text { (unconfined flows). } \\
\text { (Bown and Kraus, 1987) } \\
\end{array}$ \\
\hline C - 2 & $\begin{array}{l}\mathrm{Sp}, \mathrm{S} \\
\end{array}$ & $\begin{array}{l}\mathrm{A} \\
\mathrm{B}\end{array}$ & 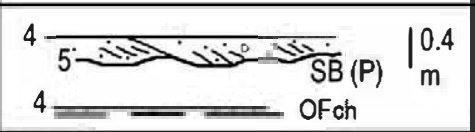 & $\begin{array}{l}\text { 3th, 4th, } \\
\text { 5th }\end{array}$ & 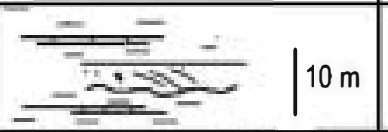 & $\begin{array}{l}\text { nnels filled with thin } \\
\text { ss and small linguid bars } \\
\text { a floodplain fine } \\
\text { (Ramos et al., 1986) }\end{array}$ \\
\hline$C-3$ & Sp, SI, & A & ${ }_{\mathrm{DA}(\mathrm{la})}{ }^{4} \mathrm{~L}^{2 \mathrm{~m}}$ & $\begin{array}{l}\text { 3th, 4th, } \\
5 \text { th }\end{array}$ & 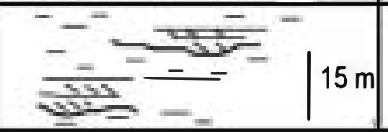 & $\begin{array}{l}\text { Vertical multistore } \\
\text { Laterally unstable } \\
\text { Grouped transver } \\
\text { sandwaves (Hirst }\end{array}$ \\
\hline C -4 & $\mathrm{Sp}$ & A & $\mathrm{DA} \stackrel{\mathrm{cosec}}{ }^{4} \mid 2 \mathrm{~m}$ & 4th, & & \\
\hline$C-5$ & $\begin{array}{l}\text { Se, Sp, } \\
\text { Gmv }\end{array}$ & $\begin{array}{l}\text { A } \\
\text { C }\end{array}$ & $\begin{array}{lll}0.000000 \\
S B\end{array}$ & 4 th & 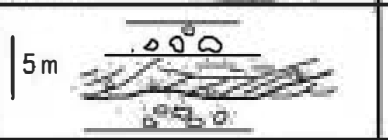 & $\begin{array}{l}\text { Linguoid-transverse bars and scour fill } \\
\text { altermating with poorly sorted normal grading } \\
\text { massive beds of volcaniclastics sediments. } \\
\text { (Lajoie and Stix, 1992) }\end{array}$ \\
\hline$C-6$ & $\begin{array}{l}\mathrm{Sp}, \mathrm{St} \\
\mathrm{Fl}, \mathrm{Sr}, \mathrm{Sh}\end{array}$ & A & $=$ & 3th, 4th & $\bar{E}$ & $\begin{array}{l}\text { Sheets of sandstone composed by } \\
\text { minor bars, scour and channel fills. } \\
\text { (Horne and Ferm, 1976). }\end{array}$ \\
\hline C. 7 & $\mathrm{Sp}, \mathrm{Sr}, \mathrm{Sh}$ & A & $3 \mathrm{~m}$ & 3th, 4th & $15 \mathrm{~m}$ & $\begin{array}{l}\text { Amalgamated complexes of } \\
\text { downstream accretion macroforms. } \\
\text { (Bristow, 1993; Bromley, 1991). }\end{array}$ \\
\hline C- 8 & $S$ & A & $0.5 \mathrm{~m}$ & $\begin{array}{l}\text { 3th, 4th, } \\
\text { 5th }\end{array}$ & $4.5 \mathrm{~m}$ & $\begin{array}{l}\text { Fluvial sandy bedf } \\
\text { crested and linguo } \\
\text { (Walker and Cant, } 198 \\
\text { Williams, 19:7 } \\
\end{array}$ \\
\hline C -9 & $\begin{array}{l}\text { Sh, Se, } \\
\text { Sf (ws) }\end{array}$ & $\begin{array}{c}A, B \\
C\end{array}$ & $\mathrm{VF}$ & 3th & $\widehat{x=1}=$ & $\begin{array}{l}\text { Dense pyroclastic fiow deposits } \\
\text { with preserved wavy layering. } \\
\text { (Lajoie and Stix, 1992; Stow, 2005). }\end{array}$ \\
\hline C - 10 & $\begin{array}{l}\text { Sh, SI, } \\
\text { SI (hm) }\end{array}$ & A & 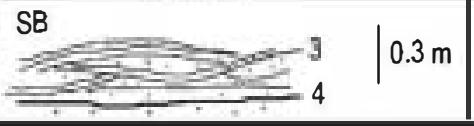 & 3th. 4th & $1.3 \mathrm{~m}$ & $\begin{array}{l}\text { Sandstone beds under near-critical flow } \\
\text { conditions. Highwaters. Storm deposits. } \\
\text { (Cotter and Graham, 1991). }\end{array}$ \\
\hline
\end{tabular}

Fig. 5. Principal differentiated sedimentary features (facies and architectural elements) and their interpretations of $\mathrm{C}-1$ to $\mathrm{C}-10$ subunits of the Tordillo Formation in Cañada Ancha area. See Table 1 for codes interpretation. 


\begin{tabular}{|c|c|c|c|c|c|c|}
\hline Subunit & Facies & & $\begin{array}{l}\text { Architectural elements } \\
\text { - Channel B- Floodplain } \\
\text { C- Volcaniclastics }\end{array}$ & \begin{tabular}{|l|} 
Bounding \\
surfaces \\
order
\end{tabular} & $\begin{array}{l}\text { Vertical stacking pattern } \\
\text { of architectural elements }\end{array}$ & Interpretation \\
\hline C - 11 & $\begin{array}{l}\text { St, Sr, } \\
\text { Sp }\end{array}$ & A & ${ }_{\mathrm{SB}}{ }_{\mathrm{CH}(\mathrm{cb})}{ }^{2}$ & $\begin{array}{l}4 \mathrm{w}_{1}, 5 \mathrm{th}, \\
3 \mathrm{t}, 2 \mathrm{th}\end{array}$ & $\sum^{2}=1.3 \mathrm{~m}$ & $\begin{array}{l}\text { Fluvial sandy bedforms. In-cliannel } \\
\text { deposits and cutbank in multistory } \\
\text { geometries. (Bridge and Mackey, 1993; } \\
\text { Walker and Cant, 1984; Ramos et al., 1986) }\end{array}$ \\
\hline C - 12 & $\begin{array}{l}\text { St, Sp, } \\
\text { Sp(rs) }\end{array}$ & A & SB $\mathrm{CH}-5$ & 4 th, 5th & $=-114 \mathrm{~m}$ & $\begin{array}{l}\text { Fluvial sandy bedforms. In-Channel } \\
\text { deposits. (Rust and Jones, 1987; } \\
\text { Lopez-Gomez and Arche, 1993). }\end{array}$ \\
\hline$C-13$ & $\mathrm{Sp}, \mathrm{Sr}$ & A & $=4.0 .6 \mathrm{~m}$ & $4 n 3 t$ & & $\begin{array}{l}\text { Amalgameted complex of fluvial sheet } \\
\text { sandstone resting on flat base. } \\
\text { (Conagham and Jones, 1975; Coleman, 1969; } \\
\text { Miall and Smith, 19ag; }\end{array}$ \\
\hline C- 14 & St, Sp, & A & \begin{tabular}{l|l}
4 & $0.4 m$
\end{tabular} & 3tu, 4t & $\left.\sum_{4}\right|_{\mathrm{m}} ^{1.2}$ & $\begin{array}{l}\text { Sinuous crested transverse and linguoid } \\
\text { bed forms with waning flood deposits. } \\
\text { (Walker and Cant, 1984; Godin, 1991). }\end{array}$ \\
\hline C -15 & $\begin{array}{l}\text { Sp (la), Fm, } \\
\text { Sr, Sh }\end{array}$ & B & $\begin{array}{l}\mathrm{SB}, \mathrm{LS} \\
\mathrm{FF}, \mathrm{LS}\end{array}$ & 3th, 2th & $\begin{array}{cc}0.3 \\
m\end{array}$ & $\begin{array}{l}\text { She日t, blanket deposits as minor bars or } \\
\text { crevasse splay interbeded with fine over- } \\
\text { bank deposits. } \\
\text { (Allen 1983; Ramos et al., 1986) }\end{array}$ \\
\hline C - 16 & $\begin{array}{l}\text { Sp (ecs) } \\
\text { FI }\end{array}$ & A & $\mathrm{OFch}$ & $3 \mathrm{n}, 4 \mathrm{~h}$ & $\left.\right|_{m} ^{0.8}$ & $\begin{array}{l}\text { Lateral-accretion. High-sinuosity nver } \\
\text { developed on overbank fines. (Allen, 1963; } \\
\text { Bridge, 1975; Alexander and Gawtiorpe, } \\
\text { 1993; Puigdefábregas, 1973) } \\
\end{array}$ \\
\hline$C-17$ & $\begin{array}{l}\mathrm{Fl}(\mathrm{pl}), \mathrm{Sp} \\
\mathrm{Fr}, \mathrm{Fm} .\end{array}$ & B & 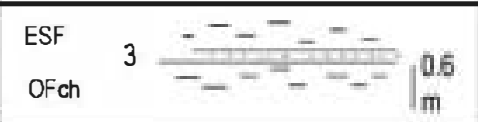 & 2tt, 3th & $\begin{array}{c}\bar{z}=\left.\right|_{\mathrm{m}} ^{2.2} \\
\bar{z} \\
\bar{z}\end{array}$ & $\begin{array}{l}\text { Overbank fine deposits with solitary } \\
\text { small transverse or linguoids bedforms } \\
\text { (Bown and Kraus, 1987). }\end{array}$ \\
\hline C - 18 & $\begin{array}{l}\text { Gmm, Gmg, } \\
\mathrm{Gcm}\end{array}$ & C & $\left.\right|_{m} ^{0.9}$ & 4 th & & $\begin{array}{l}\text { Plastic-pseudoplastic debris flow, low } \\
\text { to high strenght. Viscous to turbulent } \\
\text { or graded fow of volcaniclastic origin } \\
\text { (Rust, 1978). }\end{array}$ \\
\hline C -19 & $\begin{array}{l}\mathrm{FI}, \mathrm{FI}(\mathrm{lb}) \\
\mathrm{Sr}, \mathrm{FI}(\mathrm{pl})\end{array}$ & B & 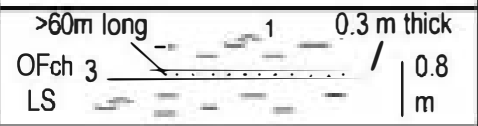 & $\begin{array}{l}1 \text { tt, } \\
2 t_{1}, 3 t_{1}\end{array}$ & 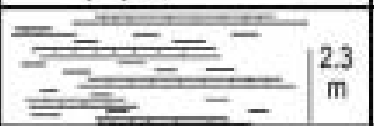 & $\begin{array}{l}\text { Flood plain deposits with fine to thick } \\
\text { blankets of overbank fine deposits } \\
\text { (Farrel, 1987). }\end{array}$ \\
\hline C. 20 & $\begin{array}{l}\mathrm{Fl}, \mathrm{Fsm} \\
\mathrm{Fr}\end{array}$ & B & $\mathrm{LS}^{<20 \mathrm{~m} \text { long }} 0.1 \mathrm{~m}$ thick & $\begin{array}{l}1 \text { th, } \\
2 \text { th, 3th }\end{array}$ & $\begin{array}{l}\bar{y} \\
\overline{-}= \\
\overline{-}\end{array}$ & $\begin{array}{l}\text { Floodplain deposits with very isolated } \\
\text { flash flood episodes and semi-permanent } \\
\text { pools (Platt and Keller, 1992). }\end{array}$ \\
\hline
\end{tabular}

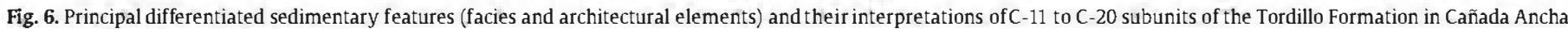
area. See Table 1 for codes interpretation.

to $\mathrm{C}-4$ (Fig. 3A). The middle unit, which includes subunits $\mathrm{C}-5$ to $\mathrm{C}-10$ (Fig. 3B-C) is represented by a complex stacking of amalgamated sandstone bodies where erosive surfaces are important and the presence of fine sediments between the bodies is very rare. The upper unit is represented by subunits $C-11$ to $C-20$ and, again, fine sediments separate amalgamated or isolated bodies in most of the subunits (Fig. 3D-E).

\subsection{The lower unit}

Subunits of the lower unit (C-1 to C-4) (Figs. 4, 5) are composed of architectural elements that have been interpreted as both channels and floodplains components. An important characteristic of the lower unit is the general coarsening-upwards trend from the $\mathrm{C}-1$ to the $\mathrm{C}-4$ subunits. This trend is especially dominant in the individual decimetre-scale sequences of subunit $\mathrm{C}-2$. Facies include fine- to medium-grained sandstones and medium- to coarse-grained sandstones towards the top. This lower unit has unconformable lower and upper contacts. The lower contact lies on a paleokarstic surface carved on the Auquilco Fm.

Bounding surfaces of architectural elements ranges from 3th to 5th order, as they show limited geographical extent and enclosed typical geometrical shapes of lithofacies associations ranging from macroforms to channels. Paleocurrents are from SW to NW. The general vertical stacking pattern of the architectural elements shows an increase in sand bodies from C-1 to C-4 subunits (Fig. 3A). Subunit C-1 is represented by floodplain deposits with isolated unconfined flows resulting in lenticular sandstone bodies, while shallow channels or channel-belt sandstones with small linguoid bars passing into floodplain deposits are represented in the $\mathrm{C}-2$ subunit (Fig. 7A). These latter bodies that are incised into, and abruptly overlain by, floodplain siltstones, could indicate deposition by avulsive braided river systems, as shown by flow diversion and possible creation of new channels. Similar examples were described by Mohring et al. (2000) in Cenozoic sediments from United States and Spain. Subunits C-3 and C-4 are interpreted as amalgamated down stream deposits with low angle cross beds and channel margin deposits, respectively ( Fig. 7 B,C).

\subsection{The middle unit}

Subunits of the middle unit (C-5 to C-10) (Figs. 3B-C, 4,5) are mostly dominated by pale brown-grey, fine- to coarse-grained sands and medium size subangular to angular conglomerates. The geometry of the sand bodies show prominent morphology. Facies, architectural 
Table 1

Key for Figs. 5 and 6.

Facies code, sedimentary structures and interpretation

FI-sand, silt, mud. Fine lamination, very small ripples. Overbank, abandoned channels or waning flood deposits.

FI (hc) - same as FI and possible halite crystal pseudomorphs.

$\mathrm{FI}(\mathrm{pl})$ - same as FI and parting lineation.

FI (lb) - same as FI and lenticular bedding.

Fm - mud, silt. Massive, desiccation cracks. Overbank, abandoned channels or drape deposits.

$\mathrm{Fr}$ - mud, silt. Massive, roots, bioturbation. Incipient soil.

Fsm - silt, mud. Massive. Backswamp or abandoned channel deposits.

Se - Erosional erosional scours with intraclasts. Crude cross-bedding. Scour fills

Sh - sand, very fine to very coarse or even pebbly. Horizontal lamination, parting or

streaming lineation. Planar bed flow (upper flow regime).

Ss - sand, very fine to coarse or even pebbly. Broad, shallow scours. Scour fills

$\mathrm{Sp}$ - sand, medium to very coarse or even pebbly. Solitary or grouped planar cross beds

linguoid and transverse bars, sand waves (lower flow regime).

$\mathrm{Sp}(\mathrm{vb})$ - same as Sp and volcanic bombs.

$\mathrm{Sp}$ (rs) - same as $\mathrm{Sp}$ with reactivation surfaces.

Sp (la) - same as Sp with low angle cross-beds.

Sp (ecs) - same as Sp with lateral accretion.

$\mathrm{Sr}$ - sand, very fine to coarse. Ripples cross-lamination. l.ower flow regime (ripples).

St - sand, fine to very coarse or even pebbly. Solitary or grouped trough cross-beds.

Sinuous-crested and linguoid dunes.

Sf (ws) - sand and fines. Flame structures and parallel lamination. Water escape structures.

SI - sand and fines. low-angle cross-beds.

SI (hm) - sand very fine to coarse. l.ow-angle cross-stratification (Hummock and swale). hummocky cross- stratification.

Gmm - matrix-supported, massive gravel. Weak grading. Plastic debris flow (highstrength, viscous)

$\mathrm{Gmg}$ - matrix-supported gravel. Inverse to normal grading. Pseudoplastic debris flow (Iow strength, viscous).

$\mathrm{Gcm}$ - clast-supported massive gravel. Pseudoplastic debris flow (inertial bedload turbulent flow)

Gp - gravel, stratified. Planar cross-beds. Transverse bedforms.

$\mathrm{Gmv}$ - massive or crudely bedded grading volcaniclastic gravels.

Architectural elements code

$\mathrm{CH}-$ channel.

$\mathrm{CH}$ (cb) - channel and cutbank

DA - Downstream downstream accretion.

DA (cb) - Downstream downstream accretion and cutbank

DA (la) - low angle downstream accretion.

$\mathrm{SB}$ - sand bed form.

SB (p) - sand bed form with planar cross-stratification

SG - Sediment sediment gravity flow.

VF - Volcaniclastic volcaniclastic flow.

OFch - Overbank overbank flow of channel (levee, crevasse and channel splay)

ESF - Ephemeral ephemeral sheet floods.

$\mathrm{FF}$ - Floodplain floodplain fines

1.S - l.aminated laminated sand.

LA - lateral accretion.

Code of facies and architectural elements is based on Miall $(1992,1996)$ classification including some new ones added by the authors.

elements, and especially bounding surfaces located among the subunits indicate important and abrupt changes in the genesis of this unit, especially from the basal subunits (C-5 to C-8) to the top subunits (C-9 to C-10).

The lower contact is an erosive unconformity with the lower unit. Conglomerate composition of subunit $\mathrm{C}-5$ shows a clear reactivation with respect to the lower unit. Only 3 paleocurrents are measured in the lower unit, 2 with northwesterly paleoflow. Presence of volcaniclastic deposits is also an important characteristic of this subunit (Fig. 7D). These latter deposits are intercalated between channels, linguoid-transverse bars of braided fluvial deposits. Subunits C- 6 to C-8 show sandy bedforms of different size that vary from sheet sandstones composed of minor bars in the C-6 subunit (Fig. 7E), amalgamated complex of downstream accretion macroforms in C-7 subunit (Fig. 7F) and small sinuous-crested bedforms with bioturbation at their top in $\mathrm{C}-8$ subunit.
The contact between C-8 and C-9 subunits is represented by an unconformity, traceable laterally, that indicates a change in the vertical evolution of this middle unit. Paleocurrents come from the $W$. Vulcanosedimentary deposits and fine- to medium grained sands with flame and load structures (Fig. 7G) are important characteristics of this subunit. Volcanic bombs frequently impacted into the sediments deforming the bed structure. The vertical succession of facies allows for the differentiation of decimetre-sacale volcanosedimentary sequences that are graded and have sharp erosive bases. These sequences are interpreted as the deposits of dense pyroclastic flows. Organic structures due to vertical bioturbation sediment disturbance appear at the top of these sequences.

Subunit C-10 constitutes the top of middle unit and represents an important change in sedimentation. Its main characteristic is the presence of hummocky-like structures (Fig. 7H) showing gently undulating low-angle lamination with small plant remains.

\subsection{The upper unit}

Subunits of the upper unit (C-11 to C-20) (Figs. 3C-D-E, 4, 6) are mostly dominated by pink to white fine to medium grained sandstones and red to brown siltstones. Volcanosedimentary deposits episodically occur towards the top of this unit.

The base of the upper unit is defined by an erosive unconformity with a sharp contact overlying subunit $\mathrm{C}-10$. Orientation of paleocurrents range from SW to NW. Bounding surfaces ranging from 2 th to 4 th order are the most representative. The main characteristic of this unit is the presence of a high percentage of fine sediments, especially towards the top of the unit, increasing from the $\mathrm{C}-15$ to $\mathrm{C}-20$ subunits.

The interval from the $\mathrm{C}-11$ to $\mathrm{C}-14$ subunits shows a general increase of fine sediments and bioturbation towards the top. Individual decimetric to metric scale fining-upward sequences are the most representative stacking patterns. Associations ofSp, St, Sr facies are the most common and constitute both fluvial sandy bedforms and channels architectural elements in the $\mathrm{C}-11$ and $\mathrm{C}-12$ subunits (Fig. 8A,B, respectively). Presence of reactivation surfaces is a significant feature of the C-13 subunit (Fig. 8C) where vertical stacking pattern of sand bodies implies braided fluvial systems with amalgamated complexes of fluvial downstream accretion macroforms composed by incomplete fining-upwards sequences. Subunit C-14 shows fining-upwards sequences (Walker and Cant's, 1984) with sinuous crested, transverse and linguoid bedforms with waning flood deposits at the top (Fig. 8D) with some bioturbated horizons and plant remains.

The interval composed by $\mathrm{C}-15$ to $\mathrm{C}-20$ subunits shows a clear increase in fine sediments (Fig. 3E) and constitutes a vertical alternation between the pale yellow and brown fine- to mediumgrained sandstones. Sheet deposits composed of minor bars with low angle planar cross-stratification developed into overbank deposits (Fig. 8E) are the most representative features of subunit C-15. Similar deposits but with increased fine deposits, punctual turbulent layers occurring in bedding planes as show the presence of parting lineation structures, and incipient soil development is recognized in C-17 subunit. Lateral accretion architectural elements (Fig. 8F) are the most representative feature of subunit $\mathrm{C}-16$. These elements usually show offlapped upper terminations, followed by fine-grained facies of the overbank fines architectural element.

Subunit C-18 represents a singular bed within the succession. Matrixand clasts-supported massive gravel (Fig. 8G) are the main facies of this subunit and constitute dense pyroclastic flow deposits, probably due to base surge transport, similar to the Laacher See eruption deposits described by Schmincke (2004). This subunit displays a kilometre-scale lateral continuity and a dominant geometry in the field (Fig. 3E).

Finally, the C-19 and C-20 subunits represent an abrupt change in sediments with respect to the previous subunits. Fine red sediments are the most representative facies and thin, fine-grained sand bodies are intercalated between them. Sand bodies are of centimeter to 

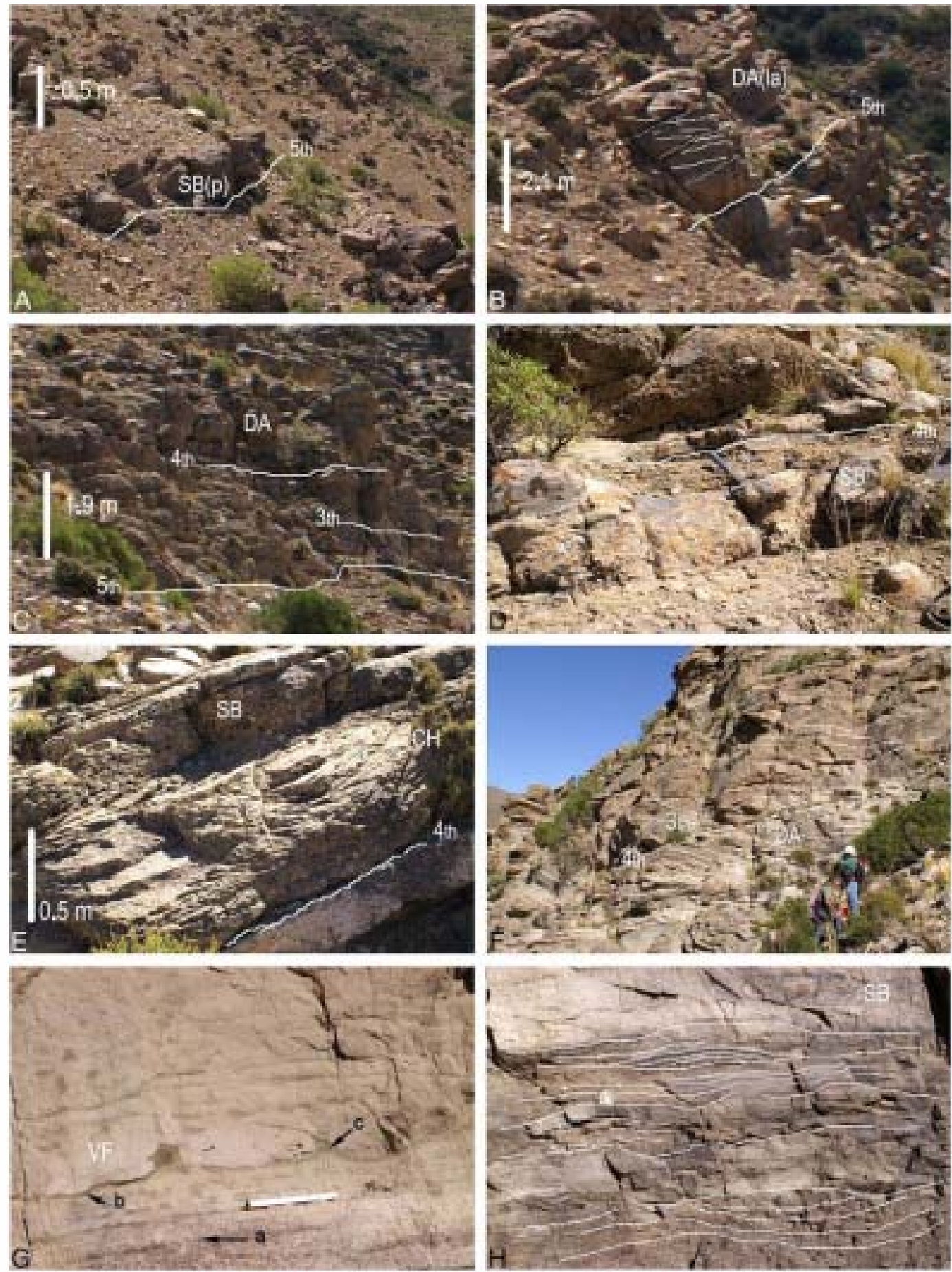

Fig. 7. Principal sedimentary features of subunits of the lower and middle units ( $C-1$ to $C-10$ ) of the Tordillo Formation. A: $C-2$, shallow channels with small linguoid bars passing into floodplain deposits; B: C-3, amalgamated down stream deposits with low angle cross beds; C: C-4, channel margin deposits; D: C-5, volcanoclastic deposits. Hammer is 33 cm long; E: C-6, sheet sandstones composed by minor bars; F: C-7, amalgamated complex of downstream accretion macroforms with paleoflows almost parallel to the picture; G: C-5, volcanosedimentary deposits and fine to medium grained sands (a), load structures (b) and flame structures (c). Pencil is $15 \mathrm{~cm}$ long; H: C-10, hummocky-like structures. Coin for scale is $23 \mathrm{~mm}$.

decimeter scale and show planar base in C-19 subunit (Fig. 8H). Similar sand bodies appear in C-20 subunit, although they are thinner and less frequent in the latter subunit. Facies associations represent overbank fines and intercalated laminated sands, and could indicate a well-drained floodplain deposits or even playa environments, similar to those described by Arche (2008) and by Lopez et al. (2008) in the Lodève Basin, France. The olive-green laminated and burrowed fine sediments could have been deposited in shallow, semi-permanent lakes or pools on the floodplain, representing the laminated fine sediments produced from the suspension fallout during floodplain inundation. Presence of lenticular bedding and oscillation ripples in subunit C-20 could suggest standing water in a floodplain environment, or even sporadically marine connection.

\section{Controls on sedimentation and paleogeografical significance}

The general architecture of alluvial sediments is controlled by a variety of autogenic and allogenic mechanisms that work simultaneously 

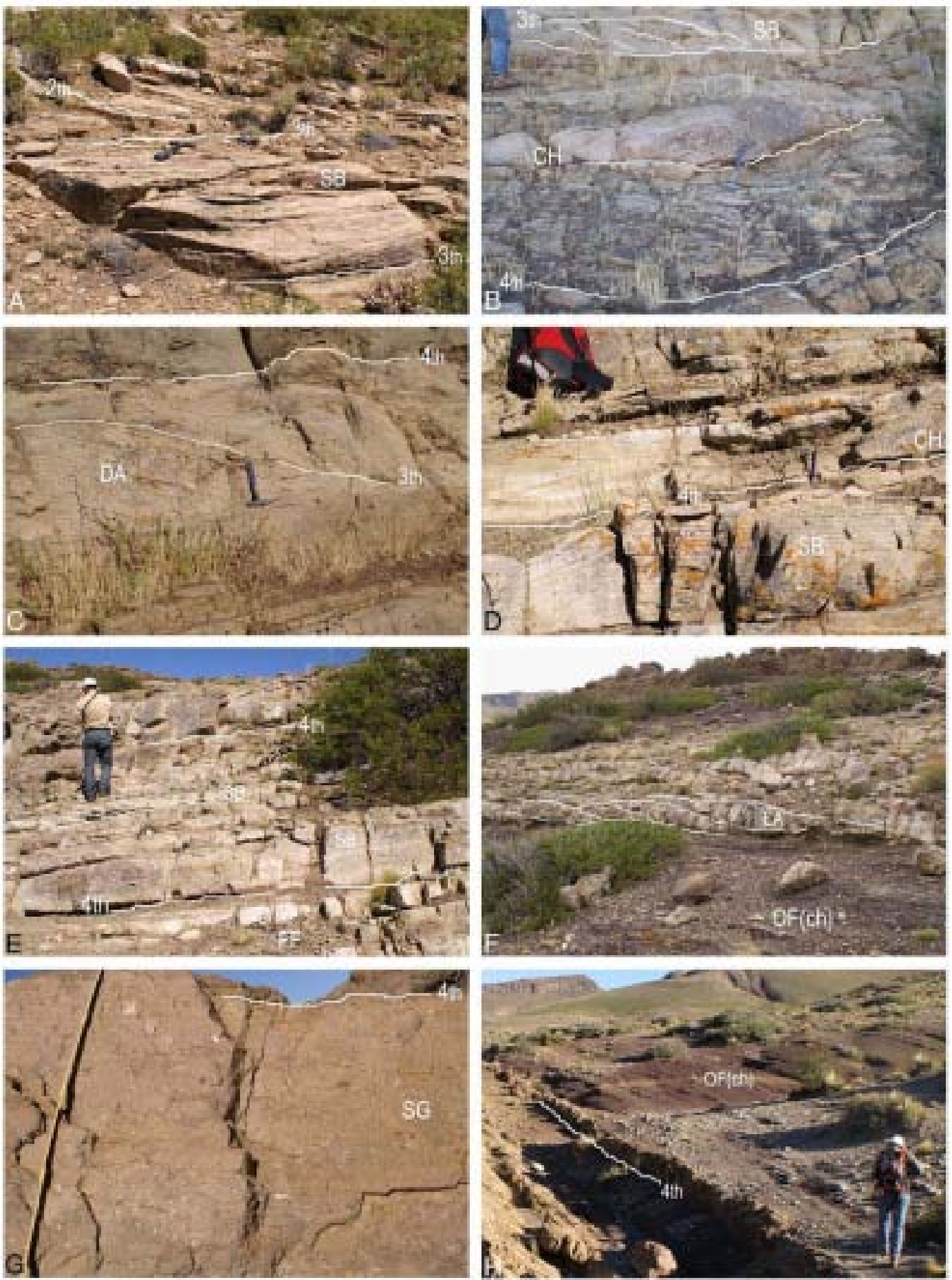

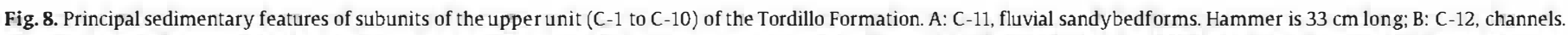

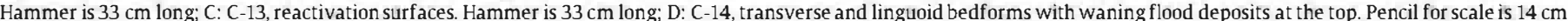

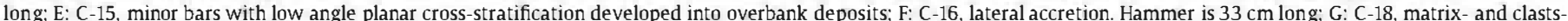
supported massive gravel and possible crude stratification. Scale is $95 \mathrm{~cm}$ long; $\mathrm{H}$ : C-19, centimetre to decimetre sand bodies intercalated between fine red sediments.

(Kraus and Middleton, 1987). Major allogenic controls on fluvial sedimentation are of tectonic and climatic origin, however, not always is easy to separate one from the other. Effects of baselevel change depends upon many factors, as the amount of charge and river character, and will be moderate in most of the cases, being accommodated by changes of channel pattern as width, depth and roughness (Schumm, 1993).

The Tordillo Formation reflects a multistage alluvial system with different fluvial styles, that experienced drastic changes in its vertical evolution mainly due to allogenic controls.

\subsection{Climate}

Clastic input in the studied section was mostly from source areas in the south-east, that is, from the uplifted blocks of the south-west area of the Neuquén Basin that resulted from the Araucarian inversion. Between this provenance source and the studied area, coeval eolian sediments were also present (Gulisano, 1988; Aguirre, 1993; Spalletti and Colombo, 2003, 2005; Zavala et al., 2005). This arid belt extended beyond the Neuquén Basin across the equator down to $50^{\circ} \mathrm{S}$ and 
created extensive sand seas in other areas of South America, as Brazil and Bolivia (Hallam, 1985).

Arid and semiarid conditions prevailed during sedimentation of the Tordillo Formation in the study area, although there was enough precipitation for, at least, seasonal or episodic fluvial runoff.

Changes in the thickness and width of the sandbodies within the different subunits suggest substantial changes in water discharge. Fluctuations of the water table and variable (seasonal?) runoff as shown in the different subunits caused oxidation, probably responsible for the low organic-matter content especially during dry seasons, as was described for different Cretaceous examples by McCabe and Parrish (1992) and Paredes et al. (2007a,b).

Meandering channels show in-channel mud deposition, with mud drapes along accretion surfaces which reflects important stage fluxes and occasional desiccation of the channel bed in response to a seasonal or ephemeral supply of water and sediments. Coarsergrained, multistorey sandstone complexes of the middle subunits contain amalgamated storeys deposited by low-sinuosity rivers also with a fluctuating, but semi- or perennial discharge, similar to deposits described Hillier et al. (2007) for the early Devonian Lower old Red Sandstone. Associated with these laterally extensive sandbodies was a high water table with surface ponding that enabled the preservation of the scarce plant detritus.

Periods of desiccation are clearly indicated by mud cracks of 12 to $15 \mathrm{~cm}$ wide and halite crystal pseudomorphs found in the lower and upper subunits of the studied section. On the other hand, laminated and burrowed reddish brown mudstones as shown in different subunits were deposited in shallow, semipermanent pools on the floodplain with laminated mudstones resulting from suspension fallout during and after floodplain inundation. During high discharge events, flow also expanded over these contemporaneous floodplain depositing sheet sandstones within splay complexes. Under these conditions, sandstone beds under near-critical flow conditions may form hummocky-like structures (Cotter and Graham, 1991).

Perennial rivers systems with seasonal fluctuations were probably subordinated in the Tordillo Formation, and mostly represented in the C-7 subunit ( Fig. 7F) and probably other subunits of the central part of the unit of the studied section, where floodplain facies were poorly developed. Intermittent systems or even flash floods coming from southern and eastern areas are commonly represented by sandstone sheets in the rest of the subunits.

\subsection{Tectonism}

Tectonic control of alluvial architecture is commonplace in different tectonic terrains. The beginning of the Mendoza Group started with the Tordillo sedimentation which occurred during the growth and eastward migration of the Andean volcanic arc and the cessation of older marine sedimentation. This emergent-arc and the intra-arc terrain were irregularly segmented by axial graben systems (Sanguinetti and Ramos, 1993), which created the space for new continental sedimentation. So, the Tordillo Formation represents an important episode of regional uplift.

The latest Oxfordian-early Kimmeridgian inversion (Araucarian inversion), preceded the sedimentation of the Tordillo Formation. After this structural event, the Neuquén Basin was significantly restricted and the erosion of previous units in the south and eastern margins of the basin was important (Vergani et al., 1995). The detailed study of the Tordillo Formation at the Cañada Ancha area allows the recognition of different bounding surfaces of great lateral continuity that separate the differentiated subunits and contrasting architectures. Most of these surfaces are clearly related to tectonic control, some of them are even unconformities (Figs. 3, 4).

The sandstone architecture of the Tordillo Formation at the Cañada Ancha section is dominated by channel-fill and sheet sands, with associated simple or complex bars. Single or weakly multistorey channel deposits encased in large quantities of overbank sediments, as observed in the subunits of the lower and upper units, would reflect more rapid rates of subsidence and sediment accumulation (Kraus and Middleton, 1987). Decreasing rates of subsidence produced thick and strongly multistorey sandbodies, as observed in the subunits of the middle unit.

Alluvial systems respond to valley-slope deformation caused by active tectonics in various ways depending on the rate of surficial deformation and the type of river (Ouchi, 1985; Schumm, 1993). Sandbody complexes of braided systems are the most representative deposits of the subunits of the middle unit of the studied section. Aggradation is dominant in these subunits and could be a response to basinal subsidence across the river in the central to downstream area of subsidence.

High subsidence rates are indicated by the large percentage of overbank mudstone, ribbon to multistorey channel geometries and lack of paleosol development that dominates in subunits of the lower and upper units. This subsidence and the regional flexure in the basin could also be induced by tectonic loading during major thrust emplacement to the west (Schuster and Steidtmann, 1987).

The main evidences of volcanic activity during deposition of the Tordillo Formation are the intercalated pyroclastic beds. Most of the volcanic deposits of this Formation reflect distal events related to stages of uplift and deformation of the Andean Chain. However, a nearby source of the surge deposits is inferred for the well-preserved glass shards (subunit C-9) and wavy layering generated by turbulent flows (subunit C-18), as the maintenance of turbulent suspension of clasts over distances longer than $30 \mathrm{~km}$ is rare (Paredes et al., 2007a,b).

Large volumes of pyroclastic material probably encroached the thickness of sediments of the Tordillo Formation westwards to the basin, close to the volcanic focuses. Immediately after the eruption, large volumes of volcaniclastic material could have been reworked from proximal areas and discharged into the distal basin. The input of episodic pyroclastic material into the basin could have also produced important changes in fluvial architecture, as observed in subunits C-9 and $\mathrm{C}-18$, rapidly returning to previous geometries and sizes of the channelized bodies. Similar changes due to recent eruptions have been observed in the Rio Grande alluvial system, in central Neuquén Basin, at the Pasarela site, where the system has been restricted in more than $90 \%$ of its wide in a section of almost a $1 \mathrm{~km}$. Descriptions of dramatic changes in fluvial architecture provoked by intermittent pyroclastic deposition in the floodplain in ancient sediments have been also shown by Fielding et al. (1993), Nakayama and Yoshikawa (1997) and Paredes et al. (2007a,b).

\subsection{Sea-level and base-level}

The whole Mendoza Group is characterized by the stacking of successive transgressive-regressive sequences (Groeber, 1946; Legarreta and Uliana, 1991). Within this dynamic, the Kimmeridgian recorded one of the most important relative sea-level fall of the Jurassic period in the Andean Basin (Hallam, 1988, 1991). A detailed study on the sedimentary response to tectonically induced sea-level fall in the Neuquén back-arc basin was recently described by Schwartz et al. (2006). These authors considered the Tordillo Formation as having been deposited during a major lowstand period within the regressive part of one of these main transgressive-regressive sequences. The sediments of the Tordillo Formation are of alluvial origin and clearly related to this stage of sedimentary response to tectonically induced sea-level fall.

During the early stages of alluvial sedimentation, fluvial systems flowed along a wide and depressed area that represented a corridor between mountain chains resulting from the general uplift caused by the growth of the eastward migration of the Andean volcanic arc. Paleoflows directions broadly indicate flow was parallel to the westward main tectonic structure (Fig. 9, lower and middle units). At the top of the formation, the general characteristics of the $34 \mathrm{~m}$ 
Proximal to distal fluvial systems

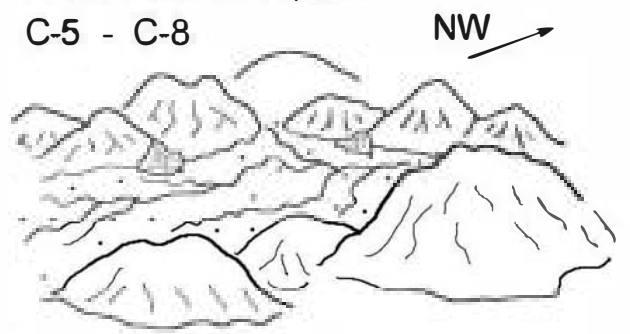

Dense pyroclastic flow deposits and medium fluvial beds under near-critical flow conditions

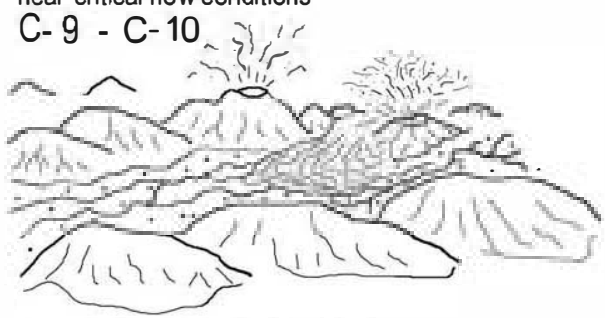

Medium to distalfluvial systems

C-19 - C-20

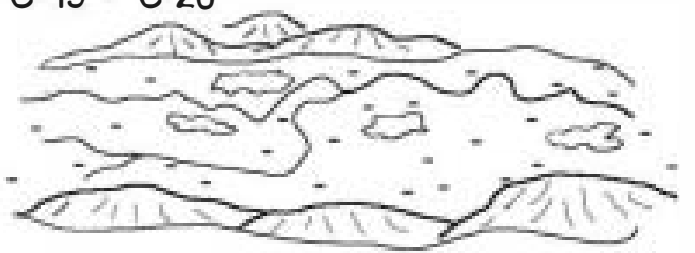

Fig. 9. Threefold tentative paleoenvironmental reconstruction of the Tordillo Formation in the study area for the lower unit (stage C-5 to C-8), middle unit (stage C-10) and upper unit (stage $\mathrm{C}-1 \mathrm{~s}$ to $\mathrm{C}-20$ ).

thick olive-green fine sediments represented by C-20 subunit clearly coincides with the ones of the so-called "Faja Verde" (Digregorio, 1972 ) at the top of the Tordillo Formation. A shift from fluvial to lake or even marine influenced setting is inferred by us for these sediments. The changes of the depositional environment occurred coeval with a sharp increase of the coastal onlap (Abbott, 1985) and reflect an adjustment of the base-level linked to a re-established full connection with the Pacific Ocean (Legarreta and Uliana, 1996). The effects of the base-level rising from $\mathrm{C}-17$ to $\mathrm{C}-20$ subunits (Fig. 9, upper unit) was probably a consequence of the landward migration of the coastline to the east, where the slope was almost flattened and the erosion very attenuated.

The main paleogeographical changes observed in the evolution of the different subunits of the Tordillo Formation show, however, short superimposed pulses of tectonic origin clearly related to the growth and eastward migration of the volcanic arc. In fact, these paleogeographical changes are linked to unconformities in the base of subunits C-5, C-9, C11 and $\mathrm{C}-18$. These pulses show a clear reactivation of the westem basin margin changing the regional paleoslope, base-level, the general paleocurrent trend, and the different alluvial sedimentary environments ranging from proximal to distal. Volcanic activity is also related to some of these tectonic events, as shown at the base of subunit C-9.

\section{Conclusions}

The study of the Upper Jurassic Tordillo Formation at the Cañada Ancha area documents the changes in fluvial architectures as the result of coeval tectonism and volcanism contributing to the better knowledge of fluvial sedimentology of back-arc basins that only few studies have previously focused. This study allows us to define a series of lithofacies, bounding surfaces and architectural elements of dominant alluvial origin. The type of sandstone body interconnections and vertical stacking patterns of these elements allowed for the recognition of the general alluvial style of the individual subunits.

A total of 20 subunits ( $C-1$ to $\mathrm{C}-20$ ) have been defined based on main bounding surfaces and the identification of architectural elements. Based on the main similarities of these alluvial styles, three units can broadly be differentiated in the Tordillo Formation:

The lower unit ( $\mathrm{C}-1$ to $\mathrm{C}-4$ ) include fine- to medium-grained sandstones and medium- to coarse-grained sandstones towards the top that ranges from floodplains deposits with isolated unconfined flows to more complex vertical multi-storey sheet sandstones representing braided fluvial systems.

The middle unit ( $\mathrm{C}-5$ to $\mathrm{C}-10$ ) is mostly dominated by pale browngrey fine- to coarse- grained sands and medium size subangular to angular conglomerates and vulcanosedimentary deposits. They display amalgamated complexes of sheet sandstones and downstream accretion macroforms interpreted as the deposits of braided fluvial systems interrupted by episodic vulcanosedimentary surge flows.

The upper unit ( $\mathrm{C}-11$ to $\mathrm{C}-20)$ is dominated by pink to white fineto medium grained sandstones and red to green siltstones, with vulcanosedimentary deposits towards the top. Architectural elements display both channels and floodplains components and ranges from amalgamated complexes of braided fluvial sheet sandstones with waning flood deposits, isolated high-sinuosity fluvial systems, flash flood deposits, and even a possible sporadic marine connection at the top of the unit.

Allogenic controls clearly controlled the general evolution of the Tordillo Formation. As shown by different sedimentary and organic structures, climate experienced successive changes ranging from arid and semiarid conditions. Tectonism reflects the eastward migration of the Andean volcanic arc and controlled the development of the bounding surfaces, subsidence, fluvial style evolution, and presence of pyroclastic flow deposits.

\section{Acknowledgements}

The manuscript benefited significantly from the comments of Dr Alfredo Arche (CSIC, Madrid) and Dr Matthew Bennett (Editor in chief), and from the very detailed and constructive revisions by the referees Dr John Holbrook and Dr Jonathan P. Allen. We also want to thank Mr. Juan Carlos Poblete for driving the car and for his enthusiastic conversations in some isolated areas of northern Neuquén basin. This work partially benefited by project UBACyT X133 and is a contribution to CAM-UCM Research Groups "Sedimentary Basin Analysis" and "Paleoclimate and Global Change" (Spain).

\section{References}

Abbott, W.O., 1985. The recognition and mapping of a basal transgressive sand from outcrop, surface, and seismic data. In: Berg, O.R., Wolverton, D.G. (Eds.), Seismic Stratigraphy II. An integrated approach: AAPG mem., vol. 39, pp. 157-168.

Allen, J.R.L., 1983. Studies in fluvial sedimentation: bars. Bar-complexes and sandstone sheets (Iow-sinuosity braided streams) in the Brown-stones (L. Devonian), Welsh Borders. Sediment. Geol. 33, 237-293.

Aguirre, C, 1993. Análisis estratigráfico-paleoambiental de la formación Tordillo en el subsuelo de la Cuenca Neuquina. $12^{*}$ Congreso Geológico Argentino, Mendoza, Actas, vol. 1, pp. 165-169.

Arche, A., 2008. Some precisions on the use of the term playa in the geologic literature. J. Iber. Geol. 34 (1), 5-10.

Bridge,J.S., 1993. Description and interpretation of fluvial deposits: a critical perspective. Sedimentology 40, 801-810.

Cas, R.A., Wright,J.V., 1987. Volcanic successions, modern and ancient. Allen and Unwin, l.ondon. $528 \mathrm{pp}$.

Cegarra, M., Ramos, V.A., 1996. l.a faja plegada y corrida del Aconcagua. In: Ramos, V.A. (Ed.), Geología de la region del Aconcagua, provincias de San Juan y Mendoza. Subsecretaría de Minería de la Nación. Dirección Nacional del Servicio Geológico. BuenosAires, pp. 387-422. Anales 24 (14).

Cotter, E, Graham, J.R., 1991. Coastal plain sedimentation in the late Devonian of Southern Ireland: hummocky cross-stratification in fluvial deposits. Sediment. Geol. 27, 201-224. 
Digregorio, J.H., 1972. Neuquen. In: l.eanza, A.F. (Ed.), Geología Regional Argentina. $12^{*}$ Congreso Geológico Argentino, Mendoza. Actas, vol. 1, pp. 165-169.

Digregorio, J.H., Uliana, M.A., 1980. Cuenca Neuquina: Segundo Simposio de Geología Regional Argentina. Acad. Nacio. Argentina 2, 985-1032.

Fielding, C.R., Falker, A.J., Scott, S.G., 1993. Fluvial response to foreland basin overfilling the l.ate Permian Rangal coal measures in the Bowen Basin, Queensland, Australia. Sediment. Geol. 85, 475-497.

Fisher, R.V., Smith, G.A. (Eds.), 1991. Sedimentation in Volcanic Settings. In: Special Publication, vol. 45. Soc. Econ. Paleont. And Mineral. 1-257 pp.

Friend, P.F., 1983. Towards the Fiels classification of alluvial architecture or sequence. In: Collinson, J.D., Lewin, J. (Eds.), Modern and ancient fluvial systems: Int. Assoc Sedimentol. Spec. Publ., vol. 6, pp. 345-354

Giambiagi, L., Bechis, F., García, V., Clark, A.H., 2008. Temporal and spatial relationships of thick-and thin-skinned deformation: a case study from the Malargüe fold-andthrust belt, Southern Central Andes. Tectonophysics 458, 123-139.

Groeber, P., 1946. Observaciones a Io largo del meridiano 70'. Asso. Geol.Arg. Reimpresiones 1, 1-174.

Gulisano, C.A., 1988. Análisis estratigráfico y sedimentológico de la Formación Tordillo en el oeste de la provincia del Neuquen, Cuenca Neuquina, Argentina. Unpublished PhD thesis, Universidad de Buenos Aires, 119p.

Gulisano, C.A., Gutierrez-Pleimling, A.R., 1994. The Jurassic of the Neuquen Basin. B Mendoza Province. Field Guide. Asociación Geológica Argentina 159, 103pp.

Gulisano, C.A., Gutierrez-Pleimling, A.R., 1995. The Jurassic of the Neuquén Basin. B) Mendoza Province. Field Guide. 4th Int. Congr. On Jurassic Stratigraphy, Mendoza: Secretaría de Minería de la Nación. Publ., vol. 159, 103pp.

Gulisano, C.A., Gutiérrez-Pempling, A.R., Digregorio, R.E., 1984. Esquema estratigráfico de la secuencia jurásica del oeste de la Provincia de Neuquen. IX ${ }^{*}$ Congreso Geológico Argentino. Actas I, pp. 236-259.

Hirst, J.P.P., 1991. Variations in alluvialarchitecture across the Oligo-Miocene Huesca fluvial system, Ebro Basin, Spain. In: Miall, A.D., Tyer, N. (Eds.), The threedimensional facies architecture of terrigenous clastic sediments, and its implications for hydrocarbon discovery and recovery: Soc. Econ. Paleont. Mineral. Conc. Sedimentol. Paleontol., vol. 3, pp. 111-121.

Hallam, A., 1985. A review of Mesozoic climates. J. Geol. Soc. (1.ond.) 142 (3), 152-168.

Hallam, A., 1988. An evaluation of Jurassic eustasy in the light of new data and the revised Exxon curve. In: Wilgus (Ed.), Sea-level changes-An integrated approach: Soc. Econ. Paleont. Mineral. Spec. Publ., vol. 42, pp. 181-193.

Hallam, A., 1991. Relative importance of regional tectonics and eustasy for the Mesozoic of the Andes. In: McDonald, D.1.M. (Ed.), Sedimentation, tectonics and eustasy. Int Assoc. Sedimentol. Spec. Publ., vol. 12, pp. 189-200.

Hillier, R.D., Marriot, S., Williams, B., Wright, P.V., 2007. Possible climate variability in the Iower Old Redsandstone Conigar Pit Sandstone Mamber (early Devonian), South Wales, UK. Sediment. Geol. 2002, 35-57.

Jones, S.J., Frostick, L.E., Astin, T.R., 2001. Braided stream and flood plain architecture: the Río Vero Formation, Spanish Pyrenees. Sediment. Geol. 139, 229-260.

Kraus, M., Middleton, L., 1987. Contrasting architecture of two alluvial suites in differen structural settings. In: Flores, G., Harvey, M.D. (Eds.), Recent developments in Fluvial Sedimentology: Soc. Econ. Paleont. Min. Spec. Publ., vol. 39, pp. 253-262.

Iegarreta, L., Gulisano, C., 1989. Análisis estratigráfico secuencial de la Cuenca Neuquina (Triásico Superior-Terciario Inferior, Argentina). In: Chebli, G.A., Spalletti, L.A (Eds.), Cuencas Sedimentarias Argentinas. Simposio de Cuencas Sedimentarias Argentinas. X Cong. Geol. Argent., Tucumán, pp. 221-243.

Iegarreta, L., Uliana, M., 1991. Jurassic-Cretaceous marine oscillations and geometry of back-ark basin fill, central argentine Andes. Special publication of the International Association of Sedimentologists $12,429-450$.

Iegarreta, L., Uliana, M., 1996. The Jurassic succession in west-central Argentina: stratal patterns, sequences and paleogeographic evolution. Palaeogeogr. Palaeoclimatol. Palaeoecol. 120, 303-330.

legarreta, L., Uliana, M.A., 1999. ElJurásico y el Cretácico de la Cordillera Principal y la Cuenca Neuquina. In: Caminos, R. (Ed.), Geología Argentina. Inlnstituto de Geología y Recursos Minerales, Buenos Aires, pp. 399-432. Anales 29.

Iopez, M., Gand, G., Garric, J., Körner, F., Schneider, J., 2008. The playa environments of the Iodève Permian basin (l.anguedoc-France). J. Iber. Geol. 34 (1), 29-56.

McCabe, P.J., Parrish, J.T., 1992. Tectonic and climatic controls on the distribution and quality of Cretaceous coals. In: McCabe, P.J., Parrish, J.T. (Eds.), Controls on the distribution and quality of Cretaceous coals: Geol. Soc. Am. Spec. Paper, vol.267, pp. $1-15$

Miall, A.D., 1985. Architecture-element analysis: a new method of facies analysis applied to fluvial deposits. Earth Sci. Rev. 22, 261-308.

Miall, A.D., 1991. Sedimentology of a sequence boundary within the nonmarine Torrivio Member, Gallup Sandstone (Cretaceous), San Juan Basin, New Mexico. In: Miall, A.D. Tyler, N. (Eds.), The Three-dimensional facies architecture of terrigenous clastic sediments, and its implications for hydrocarbon discovery and reoovery: Soc. Econ. Paleont. Mineral Conc. Sedimentol Paleont., vol. 3, pp. 224-232.

Miall, A.D. 1992. Alluvial deposits. In: Walker, R.G., James, N.P. (Eds.), Facies Models: Response to sea-level change. InGeol. Assoc. Canada, Saint John's Newfoundland, pp. $119-142$.

Miall, A.D. 1994. Reconstruction of fluvial macroform architecture from twodimensional outcrops: examples to the Castlegate Sandstone, Book Cliffs, Utah. J. Sediment. Res. 64, 146-168.

Miall, A.D., 1996. The Geology of fluvial deposits. Sedimentary Facies, Basin Analysis, and Petroleum Geology. Springer, Berlin. 582pp.

Mitchum, R.M., Uliana, M.A., 1985. Seismic stratigraphy of carbonate depositional sequences, Upper Jurassic-l.ower Cretaceous, Neuquén basin, Argentina. In: Berg, O.R., Woolverton, D.G. (Eds.), Seismic Stratigraphy II: an integrated approach to hydrocarbon exploration. AAPG Memoir, vol. 39, pp. 55-274
Mohring, D., Heller, P.L., Paola, C. 1.yons, W., 2000. Interpreting avulsion process from ancient alluvial sequences: Guadalope-Matarranya system (northern Spain) and Wasatch Formation (western Colorado). GSA Bull. 112, 1783-1803.

Nakayama, K., Yoshikawa, S., 1997. Depositional processes of primary to reworked volcaniclastics on an alluvial plain; an example from the Iower Pliocene Oht tephra bed of the Tokai Group, central Japan. Sediment. Geol. 107, 211-229.

Ouchi, S., 1985. Response of alluvial rivers to slow active tectonic movement. Geol. Soc America Bull. 96, 504-515.

Paredes, J.M., Foix, N., Colombo-Piñol, F., Nilli, A., Allard, J.O., Marquillas, R.A., 2007a Volcanic and climatic controls on fluvial style in a high-energy system: the lowe Cretaceous Matasiete Formation, Golfo de San Jorge basin, Argentina. Sediment Geol. 202, 96-123.

Paredes, J.M., Foie, M., Colombo, F., Nillni, A., Allard, J.O., Marquillas, R.A., 2007b Volcanic and climatic controls on fluvial style ina high-energy system: the l.owe Cretaceous Matasiete Formation, Golfo de San Jorge basin, Argentina. Sediment Geol. 202, 96-123.

Ploszkiewicz, J.V, Orchuela, 1.A., Vaillard, J.C., Viñes, R.F., 1984. Compresión y desplazamiento lateral en la zona de falla Huincul, estructuras asociadas, Provincia de Neuquen. Noveno Cong. Geol. Arg. Actas II, pp. 163-169.

Ramos, V.A., 1999. Plate tectonic setting of the Andean Cordillera. Episodes 22 (3) 183-190.

Ramos, A., Sopeña, A., 1983. Gravel bars in low-sinuosity streams (Permian and Triassic central Spain). In: Collison, J.D., l.ewin, J. (Eds.), Modern and ancient fluvial systems: Int Assoc Sedimentol Spec. Publ., vol. 6, pp. 301-312.

Sanguinetti, A.S., Ramos, V.A., 1993. El volcanismo del arco mesozoico. In: Ramos, V.A. (Ed.), Geología y recursos naturals de Mendoza: Relat. 12th Congr. Geol. Argent. vol. 1, pp. 115-122.

Schmincke, H.-U, 2004. Volcanism. Springer, Berlin. 324pp.

Schumm, S.A., 1993. River response to baselevel change: implications for sequence stratigraphy. J. Geol. 101, 279-294.

Schuster, M., Steidtmann, J.R., 1987. Fluvial-sandstone architecture and thrust-induced subsidence, northern Green River basin, Wyoming. In: Flores, G., Harvey, M.D. Eds.), Recent Developments in Fluvial Sedimentology: Soc. Econ. Paleont. Min. Spec. Publ., vol. 39, pp. 279-285

Schwartz, E., Spalletti, L., Howell, J.A., 2006. Sedimentary response to a tectonically induced sea-level fall in a shallow back-arc basin: the Mulichinco Formation (l.ower Cretaceous), Nuequén basin. Argentina. Sedimentology 53, 55-81.

Soegaard, K., 1992. Architectural elements of fan delta complex in Pennsylvanian Sandia Formation, Taos Trouhg, Northern New Mexico. In: Mial, A.D., Tyler, N. (Eds.), The three dimensional facies architecture of terrigenous clastic sediments, and its implications for hydrocarbon discovery and recovery: Soc. Econ. Paleont. Mineral. Conc. Models Ser., pp. 217-233.

Spalletti, L., Colombo, F., 2003. Sistemas fluviales del Jurásico Superior de la cuenca Neuquina, República Argentina. Geogaceta 33, 75-78.

Spalletti, L., Colombo, F., 2005. From alluvial fan to playa: an Upper Jurassic ephemera fluvial system, Neuquen basin, Argentina. Gondwana Res. 8 (3), 363-383.

Vergani, G.D., Tankard, A.J., Belotti, H.J., Welsink, H.J., 1995. Tectonic evolution and paleogeography of the Neuquén Basin, Argentina. In: Tankard, A.J., Suárez, S.R. Welsink, H.J. (Eds.), Petroleum Basins of South America: Am. Assoc. Pet. Geol. Memoir, vol. 62, pp. 383-402.

Walker, R.G., Cant, D.J., 1984. Sandy fluvial systems, In: Walker, R.G. (Ed.), Facies Models, 2nd Ed. Geosci. Can. Repr. Ser., vol. 1, pp. 71-89.

Zavala, C., Maretto, H., Di Meglio, M., 2005. Hierarchy of bounding surfaces in eolian sandstones of the Jurassic Tordillo Formation (Neuquén Basin, Argentina). Geol Acta 3 (2), 133-145

\section{Further Reading}

Alexander, J., Gawthorpe, R.L., 1993. The complex nature of a Jurassic multisrorey, alluvial sandstone body, Whitby, North Yorkshire. In: North, C.P. Prosser, D.J. (Eds.) Characterization of fluvial and aeolian reservoirs. In: Spec. Publ., vol. 73. Geological Society, l.ondon, pp. 123-142.

Bridge, J.S., 1975. Computer simulation of sedimentation in meandering streams. Sedimentology 22, 3-44.

Bridge, J.S., Mackey, S.D., 1993. A revised alluvial stratigraphy model. In: Marzo, M. Puigdefábragas, C. (Eds.), Alluvial Sedimentation: Int. Assoc. Sedimentol. Spec Publ., vol. 17, pp. 319-336.

Bown, T.M., Kraus, M., 1987. Integration of channel and floodplain suits, I. Development of sequence and lateral erlations of alluvial paleosols. J. Sediment. Petrol. 57, $587-601$.

Bristow, C.S., 1993. Sedimentary structures exposed in bar tops in the Brahmaputra River, Bangladesh. In: Best, J.L., Bristow, C.S. (Eds.), Braided rivers: Geol. Soc. l.ond Spec. Publ., vol. 75, pp. 277-289.

Bromley, M.H., 1991. Architectural features of the Kayenta Formation (l.ower Jurassic), Colorado Plateau, USA: relationship to salt tectonics in the Paradox Basin. Sediment Geol. 73, 77-99.

Coleman, J.M., 1969. Brahmaputra river: channel processes and sedimentation. Sediment Geol. 3, 129-239.

Conagham, P.J., Jones, J.G., 1975. The Hawkesbury Sandstone and the Brahamaputra: a depositional model for continental sheet sandstones. J. Geol. Soc. Aust. 22, 275-283.

Farrel, K.M., 1987. Sedimentology and facies architecture of overbank deposits of the Mississippi River, False River region, Iouisiana. In: Ethridge, F.G., Flores, R.M. Harvey, M.D. (Eds.), Recent developments in fluvial sedimentology: Soc. Econ. Paleont. Mineral. Spec. Publ., vol. 39, pp. 111-120. 
Godin, P., 1991. Fining-upward cycles in the sandy-braided river deposits of the Westwater Canyon Member (Upper Jurassic), Morrison Formation, New Mexico. Sediment. Geol. 70, 61-82

Hoplins, J.C., 1985. Channel-fill deposits formed by aggradation in deeply scoured superimposed distributaries of the Iower Kootenai Formation. J. Sediment. Petrol. $55,42-52$.

Horne, J.C., Ferm,J.C., 1976. Carboniferous depositional environments in the Pocahontas Basin, eastern Kentuky and sudern West Virginia, Guidebook. Department of Geology, University of South Carolina.

1.ajoie, J., Stix.J., 1992. Volcaniclastic rocks. In: Walker, R.,James, N.P. (Eds.), Facies Models Response to sea level change. InGeological Association of Canada, pp. 101-118.

1.awrence, D.A., Williams, B.P.J., 1987. Evolution of drainage systems in response to Acadian deformation: the devonian battery point formation, eastem Canada In: Ethridge, F.G. Flores, R.M., Harvey, M.D. (Eds.), 1987. Recent Developments in Fluvial Sedimentology: Soc. Eon. Paleontol Mineral. Spec. Publ., vol. 39, pp. 287-300.

1.ópez-Gómez, J., Arche, A., 1993. Architecture of the Cañizar fluvial sheet sandstones. In: Marzo, M., Puigdefábregas, C. (Eds.), Alluvial Sedimentation: Spec. Publ. Int. Ass. Sediment., vol. 17, pp. 363-381.
Miall, A.D., Smith, N.D., 1989. Rivers and their deposits. Soc. Econ. Paleont. And Mineral., Tulsa. Oklahoma. Slide 3.

Platt, N.H., Keller, B., 1992. Distal alluvial deposits in a foreland basin setting-the Iower Freshwater Molasse (l.ower Miocene), Switzerland: sedimentology, architecture and palaeosols. Sedimentology 39, 545-565.

Puigdefábregas, C., 1973. Miocene poin-bar deposits in the Ebro basin, northern Spain Sedimentology 20, 133-144

Ramos, A., Sopeña, A., Perez-Arlucea, M., 1986. Evolution of Buntsandstein fluvial sedimentation in the northwest Iberian Ranges (Central Spain). J. Sediment. Petrol. $56,862-875$

Rust, B.R., 1978. A classification of alluvial channels systems. In: Miall, A.D. (Ed.), Fluvial Sedimentology: Can. Soc. Petrol. Geol. Mem., vol. 5, pp. 187-198.

Rust, B.R., Jones, B.G., 1987. The Hawkesbury Sandstone south of Sidney, Australia: Triassic analogue for the deposit of a large braided river. J. Sediment. Petrol 57, $222-233$

Stow, D.A.V., 2005. Sedimentary rocks in the field. A colour Guide. Manson Publishing, l.ondon. 320pp. 